\title{
EVALUATION OF MITOCHONDRIAL DNA ISOLATION METHODS FOR OIL PALM (Elaeis guineensis) LEAF
}

\author{
AZIMI NURAZIYAN*; SIEW-ENG OOI* and MEILINA ONG-ABDULLAH ${ }^{\star}$
}

\begin{abstract}
An efficient preparation of pure and intact mitochondrial deoxyribonucleic acid ( $m t D N A)$ that is free from nuclear DNA contamination is a prerequisite to study the molecular complexities of the organellar genome and gene structure in oil palm. Different extraction methods have been reported for mtDNA isolation from different plants. Using oil palm leaf tissues that are present in abundance, three methods were tested and modified to isolate mtDNA. The methods used vary primarily at the purification steps, either by using phenol/chloroform or density gradient centrifugation. High ionic alkaline buffer coupled with differential centrifugation were employed in Method I. While Methods II and III utilised the discontinuous sucrose and Percoll gradient centrifugation for mitochondria isolation, respectively. Method III provided good quality mtDNA from green leaves, yielding $\sim 6.3 \mu \mathrm{g} \mathrm{g}^{-1}$ tissue. Restriction digest and polymerase chain reaction (PCR) for regions specific to mitochondrial, nuclear and chloroplast DNA further verified the quality of the mtDNA from Method III, which had the least plastid DNA contamination. Method III that incorporated Percoll density gradient centrifugation was the most efficient and provided good quality mtDNA without nuclear DNA contamination for sequencing applications and studies requiring pure mtDNA.
\end{abstract}

Keywords: mtDNA, Percoll density gradient centrifugation, sucrose gradient, chloroplast DNA.

Received: 17 November 2020; Accepted: 12 January 2021; Published online: 16 March 2021

\section{INTRODUCTION}

Mitochondria in plants, as in other eukaryotes, are the major producers of adenosine triphosphate (ATP) via oxidative phosphorylation. Many important secondary functions such as synthesis of nucleotides, amino acids, lipids and vitamins are performed by this organelle. Mitochondria also play an essential role in plant cell death and react to cellular signals such as oxidative stress (Eubel et al., 2007). The wide range of complexities in mitochondrial genomes, its involvement in cytoplasmic male sterility and abiotic stress tolerance had triggered research interest on mitochondria of higher plants.

\footnotetext{
Malaysian Palm Oil Board,

6 Persiaran Institusi, Bandar Baru Bangi,

43000 Kajang, Selangor, Malaysia.

E-mail: meilina@mpob.gov.my
}

The membrane-bound organelles in the plant cell, nucleus, mitochondria and chloroplast, produce a mix of nucleic acids through total cellular extraction. However, enriched nucleic acid from highly purified mitochondrial fractions is crucial for detailed mitochondrial deoxyribonucleic acid (mtDNA) analysis in genomic, proteomic and metabolic function studies (Binder, 1995; Sweetlove et al., 2007).

In maize, Arabidopsis, sugarcane and rapeseed, a phenol/chloroform extraction method is adequate to obtain mtDNA pure enough for restriction endonuclease digestion (Mackenzie 1994; Klein et al., 1998; Virupakshi and Naik, 2007; Hu et al., 2012). For other plants, a combination of differential centrifugation and sucrose, polyvinylpyrrolidone (PVP) and/or Percoll as well as cesium chloride $(\mathrm{CsCl})$ gradients was required to purify mtDNA (Douce et al., 1977; Neuburger et al., 1982; Day et al., 1985; Skubatz and Bendich, 1990; Moore et al., 
1993; Rahman and Huber, 1996; Hausmann et al., 2003). These approaches were implemented in mtDNA extraction from photosynthetic shoots or leaves from Arabidopsis (Klein et al., 1998), soyabean (Hrubec et al., 1985) and rapeseed (Hu et al., 2012), but no method has been reported for oil palm to date. Therefore, several methods were explored, optimised and compared towards establishing an efficient extraction method for mtDNA from oil palm green leaves that is suitable for downstream applications requiring pure $\mathrm{mtDNA}$.

\section{MATERIALS AND METHODS}

\section{Plant Materials}

Elaeis guineensis leaf sample (100 g) was stored in a $4^{\circ} \mathrm{C}$ cold room for at least $72 \mathrm{hr}$ to reduce polysaccharide or starch content. The leaves were then cut into small pieces $(\sim 1 \mathrm{~cm} \times 1 \mathrm{~cm})$ prior to extraction with each method detailed below. Total cellular DNA of oil palm (gDNA), which was used as a control, was isolated using a hexadecyltrimethylammonium bromide (CTAB)-based method (Doyle and Doyle, 1990).

\section{MtDNA Extraction Methods}

Three extraction methods were tested and optimised to select the best method providing pure and high quality mtDNA. The first extraction method was adopted from Virupakshi and Naik (2007), the second from Hanson et al. (1986) and the third method was based on Binder and Grohmann (1995), Binder (1995) and Mourad (1998); the methods are designated as Methods I, II and III, respectively. All mtDNA extraction steps were carried out at $4^{\circ} \mathrm{C}$ unless stated otherwise.

\section{Method I}

Leaf samples (100 g) were homogenised in a Waring blender (2-speed, Model 7011S) with $1500 \mathrm{ml}$ of ice-cold MTEN buffer (400 mM mannitol, $50 \mathrm{mM}$ Tris- $\mathrm{HCl} \mathrm{pH} 7.8,1.5 \mathrm{M}$ sodium chloride $(\mathrm{NaCl}), 25$ $\mathrm{mM}$ EDTA-Na $\mathrm{pH}_{2}$ 8.0). One percent bovine serum albumin(BSA), $0.1 \%$ cysteine and $5 \%$ PVP were added immediately prior to $5 \mathrm{sec}$ strokes at high speed for three cycles. The resulting homogenate was filtered through two layers of muslin cloth, followed by two layers of miracloth (Calbiochem) and the filtrate was centrifuged at $1300 \times \mathrm{g}$ for $10 \mathrm{~min}$. The supernatant was transferred to a new tube and recentrifuged at $3800 \times \mathrm{g}$ for $20 \mathrm{~min}$. To sediment the mitochondria, the supernatant was again transferred to a new tube and centrifuged for $30 \mathrm{~min}$ at a much higher speed of $29800 \times \mathrm{g}$. The mtDNA pellet was then washed thrice with $25 \mathrm{ml}$ TENC buffer $(100 \mathrm{mM}$ Tris- $\mathrm{HCl}$ $\mathrm{pH} 7.8,100 \mathrm{mM} \mathrm{NaCl}, 50 \mathrm{mM}$ EDTA-Na $\mathrm{N}_{2} \mathrm{pH}$ 8.0. $0.1 \%$ cysteine, $0.1 \%$ BSA and $1 \%$ PVP were added immediately before use) at $29800 \times \mathrm{g}$ for $10 \mathrm{~min}$. The pellet was gently resuspended in $5 \mathrm{ml}$ MT buffer (400 mM mannitol, 50 mM Tris- $\mathrm{HCl}$ pH 8.0) using a soft paintbrush. Magnesium sulphate $\left(\mathrm{MgSO}_{4}\right)$ and deoxyribonuclease (DNase) were added to a final concentration of $20 \mathrm{mM}$ and $5 \mathrm{mg} \mathrm{ml}^{-1}$, respectively and incubated at $37^{\circ} \mathrm{C}$ for $1 \mathrm{hr}$. DNAse activity was halted by washing with 3 volumes of NEDF buffer (50 mM Tris- $\mathrm{HCl}$ pH 8.0, $1 \mathrm{M} \mathrm{NaCl}, 50$ mM EDTA-Na $\mathrm{pH} 8.0,2 \%$ DEPC and $50 \mathrm{mM}$ sodium fluoride) at 29 $800 \times \mathrm{g}$ for $10 \mathrm{~min}$. The pellet was resuspended in TE buffer (10 mM Tris-HCl pH 8.0,1 mM EDTA-Na ${ }_{2}$ pH 8.0) before protein lysis at $37^{\circ} \mathrm{C}$ for $1 \mathrm{hr}$ with a final concentration of $1 \%$ sodium dodecyl sulphate (SDS) and $10 \mu \mathrm{g} \mathrm{ml}^{-1}$ proteinase $\mathrm{K}$. An equal volume of TEsaturated phenol was then added to the mixture and centrifuged at $21900 \times \mathrm{g}$ for $10 \mathrm{~min}$. Subsequently, an equal volume of chloroform/isoamyl alcohol $(24: 1, \mathrm{v} / \mathrm{v})$ was added to the upper layer, mixed and centrifuged at $15200 \times \mathrm{g}$ for $10 \mathrm{~min}$. The $\mathrm{mtDNA}$ was precipitated in 0.1 volume of $3 \mathrm{M}$ sodium acetate ( $\mathrm{pH} 4.8$ ) and 2 volumes of chilled absolute ethanol. The mtDNA pellet was then washed with $70 \%$ (v/v) ethanol, air-dried and resuspended in $200 \mu \mathrm{l}$ of TE buffer. Three microliters of ribonuclease $(20 \mathrm{mg}$ $\mathrm{ml}^{-1}$ ) were added and the mixture was incubated at $37^{\circ} \mathrm{C}$ for $1 \mathrm{hr}$. An equal volume of chloroform/ isoamyl alcohol (24:1, v/v) was added followed by centrifugation at $15200 \times \mathrm{g}$ for $10 \mathrm{~min}$. The mtDNA was precipitated in 0.1 volume of $3 \mathrm{M}$ sodium acetate ( $\mathrm{pH} 4.8$ ) and 2 volumes of chilled absolute ethanol. Finally, the mtDNA was washed with $70 \%(\mathrm{v} / \mathrm{v})$ ethanol, air-dried, resuspended in TE buffer and stored at $-20^{\circ} \mathrm{C}$ until further use.

\section{Method II}

Leaves (100 g) were mixed into 1 litre of tissue grinding buffer (0.3 M mannitol, $50 \mathrm{mM}$ Tris- $\mathrm{HCl}$ pH 8.0, 3 mM EDTA pH 8.0, 0.1\% BSA, 1\% PVP and $9 \mathrm{mM} \beta$-mercaptoethanol) and homogenised using a Waring blender for $5 \mathrm{sec}$ at high speed in three cycles. The resulting homogenate was filtered through four layers of muslin cloth, followed by two layers of miracloth. The filtrate was centrifuged at $2000 \times \mathrm{g}$ for $10 \mathrm{~min}$ to separate the bulk of nuclei, plastids and cellular debris. The supernatant was then centrifuged for $30 \mathrm{~min}$ at $10000 \times \mathrm{g}$ to sediment the mitochondria. The resulting pellet was carefully resuspended in $25 \mathrm{ml}$ of DNase digestion buffer $(0.3$ $\mathrm{M}$ mannitol, $50 \mathrm{mM}$ Tris- $\mathrm{HCl} \mathrm{pH}$ 8.0, $10 \mathrm{mM}$ ethylene glycol-bis(2-aminoethylether)- $N, N, N^{\prime}, N^{\prime}$-tetraacetic acid (EGTA), 5 mM EDTA pH 8.0, 0.2\% BSA, 50 mM $\left.\mathrm{MgCl}_{2}\right)$. After that, $500 \mu \mathrm{l}$ of DNase $\left(10 \mathrm{mg} \mathrm{ml}^{-1}\right)$ was added to the suspension and incubated for $30 \mathrm{~min}$ on ice. One milliliter of $0.5 \mathrm{M}$ EDTA was added to stop 
the reaction and the sample was diluted with $150 \mathrm{ml}$ of gradient buffer ( $0.3 \mathrm{M}$ sucrose, $50 \mathrm{mM}$ Tris- $\mathrm{HCl} \mathrm{pH}$ 8.0, 20 mM EDTA pH 8.0, 0.1\% BSA). Mitochondria were harvested by centrifuging the sample for 15 $\min$ at $16000 \times \mathrm{g}$. The pellet was then resuspended in $6 \mathrm{ml}$ gradient buffer using a paintbrush. The mitochondria suspension was carefully layered over the discontinuous sucrose gradient consisting of $1 \mathrm{ml} 2 \mathrm{M}$ sucrose, $3 \mathrm{ml}$ each of $1.6 \mathrm{M}$ and $1.2 \mathrm{M}$ sucrose, and $2 \mathrm{ml} 0.6 \mathrm{M}$ sucrose in $50 \mathrm{mM}$ Tris- $\mathrm{HCl} \mathrm{pH} 8.0$, $10 \mathrm{mM}$ EDTA pH 8.0, 0.2\% BSA, and $10 \mathrm{mM}$ tricine $\mathrm{pH}$ 7.2. The gradients were then spun in a Beckman ultracentrifuge with SW41 swinging-bucket rotor at $25000 \mathrm{rpm}$ for $1 \mathrm{hr}$. The mitochondria fraction was removed from the $2 \mathrm{M}$ to $1.6 \mathrm{M}$ interphase with a pipette and slowly diluted with 3 volumes of gradient buffer over a $15 \mathrm{~min}$ period to minimise disruption by osmotic shock. Mitochondria were then harvested by centrifugation at $15000 \times \mathrm{g}$ for $10 \mathrm{~min}$. Subsequently, the mitochondria pellet was resuspended in $7 \mathrm{ml}$ of HTE buffer $(50 \mathrm{mM}$ Tris$\mathrm{HCl} \mathrm{pH}$ 8.0, $20 \mathrm{mM}$ EDTA pH 8.0) prior to lysis with $350 \mu \mathrm{l}$ of $10 \%$ sarcosyl $(\mathrm{w} / \mathrm{v})$ and $10 \mu \mathrm{l}$ of proteinase $\mathrm{K}\left(20 \mathrm{mg} \mathrm{ml}^{-1}\right)$ for $30 \mathrm{~min}$ on ice. The mitochondria lysate was mixed with $8.05 \mathrm{~g}$ of $\mathrm{CsCl}$ and $220 \mu \mathrm{l}$ of ethidium bromide $\left(10 \mathrm{mg} \mathrm{ml}^{-1}\right)$, transferred to a Beckman Quick-Seal tube (NVT100) and subjected to isopycnic centrifugation on $\mathrm{CsCl}$ gradient at $65000 \mathrm{rpm}$ for $10 \mathrm{hr}$ at $20^{\circ} \mathrm{C}$. Subsequently, the mtDNA band was collected using a syringe under UV light. Ethidium bromide (EtBr) was then removed from the mitochondria using isopropanol equilibrated with CsCl-saturated TE buffer. MtDNA was dialysed against 4 litres of TEN buffer $(10 \mathrm{mM}$ Tris-HCl pH 8.0, $5 \mathrm{mM}$ EDTA, $50 \mathrm{mM} \mathrm{NaCl}$ ) for $4 \mathrm{hr}$. Finally, the mtDNA was precipitated in 0.1 yolume of $3 \mathrm{M}$ sodium acetate ( $\mathrm{pH} 7.0$ ) and 2.5 volumes of absolute ethanol, washed with $70 \%$ (v/v) ethanol, air dried and dissolved in TE buffer.

\section{Method III}

Leaves $(100 \mathrm{~g})$ were homogenised in a Waring blender with $1500 \mathrm{ml}$ of grinding buffer (400 $\mathrm{mM}$ mannitol, $25 \mathrm{mM}$ 3-Morpholinopropane-1sulphonic acid (MOPS) pH 7.8, 1 mM EGTA pH 8.0) for 5 sec at high speed for three times, with a $30 \mathrm{sec}$ pause in between. Prior to homogenisation, a final concentration of $0.1 \% \mathrm{BSA}$ and $40 \mathrm{mM}$ $\beta$-mercaptoethanol were immediately added. The homogenate was then strained through four layers of muslin cloth pre-wetted with isolation medium, followed by two layers of miracloth. The filtered extract was further purified via differential centrifugation at $3500 \times \mathrm{g}$ for $5 \mathrm{~min}$ and the supernatant was centrifuged for $30 \mathrm{~min}$ at $18000 \times \mathrm{g}$. The resultant organelle pellet was gently resuspended in $5 \mathrm{ml}$ of DNase I buffer $(300 \mathrm{mM}$ mannitol, $50 \mathrm{mM}$ Tris- $\mathrm{HCl} \mathrm{pH}$ 7.5, $5 \mathrm{mM} \mathrm{MgCl}_{2}$,
$10 \mathrm{mM} \mathrm{KH} \mathrm{PO}_{4}$ and $4 \mathrm{mM} \beta$-mercaptoethanol) using a paintbrush. The volume was adjusted to 25 $\mathrm{ml}$ with DNase I buffer. Then $7 \mathrm{mg}$ of DNase was added to the suspension and incubated on ice for $1 \mathrm{hr}$ to remove the remaining nuclear and chloroplastderived DNA. After that, $5 \mathrm{ml}$ of $0.5 \mathrm{M}$ EDTA was added to the suspension to deactivate the DNase. The suspension was then adjusted to a final volume of $250 \mathrm{ml}$ with DNase I buffer before centrifugation at $18000 \times \mathrm{g}$ for $30 \mathrm{~min}$. The supernatant was discarded and the pellet was washed three times with DNase I buffer containing $5 \mathrm{mM}$ EDTA. Following that, the pellet was resuspended in $6 \mathrm{ml}$ of wash medium buffer (400 mM mannitol, $5 \mathrm{mM}$ MOPS $\mathrm{pH}$ 7.5, 1 mM EGTA pH 8.0, freshly added 0.1\% BSA) and carefully homogenised by two strokes in the Ultra Turrax ${ }^{\circledR}$ T25 before transferring onto a freshly prepared Percoll step gradient. The Percoll gradient composed of $1.8 \mathrm{ml} 45 \%$ Percoll, $3.6 \mathrm{ml} \mathrm{28 \%} \mathrm{Percoll}$ and $3.6 \mathrm{ml}$ of $14 \%$ Percoll (bottom to the top layer). Each Percoll solution contained $400 \mathrm{mM}$ mannitol, 20 $\mathrm{mM}$ Tricine $\mathrm{pH} 7.2$ and $1 \mathrm{mM}$ EGTA. The gradients were then centrifuged for $48 \mathrm{~min}$ at $19700 \mathrm{rpm}$ in an ultracentrifuge (SW41Ti rotor, Beckman Coulter, USA). The mitochondria band that appeared at the interphase between $28 \%$ and $45 \%$ Percoll layers was gently removed with a pipette and diluted with 3 volumes of wash medium buffer prior to centrifugation at $18000 \times \mathrm{g}$ for $30 \mathrm{~min}$. Dilution and centrifugation was repeated thrice to get rid of Percoll before resuspending the mitochondria in HTE buffer (50 mM Tris pH 8, 25 mM EDTA pH 8) and stored at $-80^{\circ} \mathrm{C}$ until further use.

Mitochondria were lysed for an hour at $37^{\circ} \mathrm{C}$ in lysis buffer (5\% sodium sarcosinate, $50 \mathrm{mM}$ Tris$\mathrm{HCl} \mathrm{pH} \mathrm{8,} 25 \mathrm{mM}$ EDTA) containing $7 \mathrm{mg}$ proteinase K. Final purification of mtDNA was performed by isopycnic centrifugation on $\mathrm{CsCl}$ density gradients. Solid $\mathrm{CsCl}$ at a ratio of $1 \mathrm{~g} \mathrm{ml}^{-1}$ of final suspension and $10 \mathrm{mg} \mathrm{ml}^{-1} \mathrm{EtBr}$ were added, mixed and ultracentrifuged (SW41Ti, Beckmen Coulter, USA) at $41000 \mathrm{rpm}$ for $24 \mathrm{hr}$ at $19^{\circ} \mathrm{C}$. After that, the mtDNA band was visualised via a ultraviolet (UV) hand-held lamp and the respective band was collected from the centrifuge tubes using a syringe needle. $\mathrm{EtBr}$ was then extracted four times using isopropanol equilibrated with $\mathrm{NaCl}$-saturated water. Dialysis was then carried out using 2 litres of LTE buffer $(10 \mathrm{mM}$ Tris $\mathrm{pH} 8,0.1 \mathrm{mM}$ EDTA pH 8) with two changes of fresh buffer over a period of $48 \mathrm{hr}$. The mtDNA was then precipitated in 0.1 volume of $3 \mathrm{M}$ sodium acetate ( $\mathrm{pH}$ 5.0) and 2 volumes of absolute ethanol. Finally, the mtDNA was washed with $70 \%(\mathrm{v} / \mathrm{v})$ ethanol, airdried, dissolved in LTE buffer and stored at $-20^{\circ} \mathrm{C}$.

\section{Evaluation of mtDNA}

The purity and quantity of mtDNA isolated by each method was assessed using Nanodrop and 
Qubit $^{\circledR} 2.0$ fluorometer analysis, respectively. The integrity of DNA was assessed by gel electrophoresis. Approximately $1 \mu \mathrm{g}$ of mtDNA was electrophoresed on a $1 \%$ agarose gel, stained with EtBr and visualised with the G: BOX Chemi XX9 (Syngene).

The purity of each sample was evaluated further through restriction enzyme analysis. Approximately 1.0-1.5 $\mu \mathrm{g}$ of DNA was digested with EcoRV (New England Biolabs-NEB, USA) according to the manufacturer's instructions. Finally, the restriction digested product was visualised through $1 \%$ agarose gel electrophoresis under UV illumination.

\section{Assessing Chloroplast and Nuclear DNA Contamination using PCR}

The cytochrome $c$ oxidase subunit III, coxIII (Duminil et al., 2002), actin (Accession No. XM_029261651) and non-coding regions of trnL (UAA) intron of chloroplast DNA (cpDNA) (Taberlet et al., 1991) genes were selected for evaluation of the isolated mtDNA (Table 1). PCR was conducted in the Mastercycler® Pro (Eppendorf, Germany) in a final volume of $25 \mu \mathrm{l}$ containing $50 \mathrm{ng}$ DNA template, 5X Buffer, $0.2 \mathrm{mM}$ dNTP, $10 \mathrm{mM}$ of each primer and 2.5 units of Taq polymerase (NEB, USA). PCR conditions were as follow: $95^{\circ} \mathrm{C}$ for $7 \mathrm{~min}$, followed by 30 cycles at $95^{\circ} \mathrm{C}$ for $1 \mathrm{~min}, 55^{\circ} \mathrm{C}(\operatorname{cox} I I I, \operatorname{trn} \mathrm{L})$ or $60^{\circ} \mathrm{C}$ (actin) for $90 \mathrm{sec} ; 72^{\circ} \mathrm{C}$ for $2 \mathrm{~min}$, and a final extension step of $72^{\circ} \mathrm{C}$ for $5 \mathrm{~min}$. Total cellular DNA isolated from oil palm leaf was used as a positive control and a no template negative control was included. The amplified products were resolved by electrophoresis on a $1 \%$ agarose gel, stained with EtBr and visualised under UV illumination.

\section{RESULTS AND DISCUSSION}

\section{Comparison of mtDNA Extraction Methods}

The isolation of mitochondria from plants is particularly challenging as plant tissues tend to contain polysaccharides, phenolic compounds and oxidation products that co-purify with organellar
DNA. Mitochondria are also fragile and can be contaminated with broken chloroplasts and thylakoid membranes, which has a similar density to mitochondria (Hanson et al., 1986; Sweetlove et al., 2007; Lang and Burger, 2007). Different mtDNA isolation approaches were conducted to assess the suitability of each extraction method for oil palm green leaves.

As approximately only $1 \%$ of the plant total cellular content is mtDNA (Day, 1997), its abundance in the tissue sample would be important to ensure sufficient quantities of mitochondria can be obtained. Although etiolated and non-green tissues often give better mtDNA yields than green tissues (Hanson et al., 1986), the use of non-green tissues is usually hampered by the limitation of samples, as in the case for the oil palm. Therefore, green tissues are usually used as the starting material even though it contains higher concentrations of phenolics and other potentially damaging compounds to the mitochondria during the isolation process.

A few important factors were considered to minimise the degradation of mitochondria. Firstly, mitochondria were isolated using a buffer comprising EDTA or EGTA, BSA and a sulphydryl reagent such as 2-mercaptoethanol. These components help to overcome acidity, the presence of phenolic compounds and oxidation products in the tissue extract that can lead to rapid inactivation of the mitochondria (Hu et al., 2012). Secondly, to obtain maximum recovery of intact mitochondria, minimal grinding is encouraged using a Waring blender while working in the cold. Moreover, optimisation of the tissue amount to grinding buffer ratio was conducted to minimise the effects from vacuoles, particularly from the release of vacuolar contents (inorganic and organic molecules) that may damage plant mitochondria. The ratio of grinding buffer to grams fresh weight could be increased up to 40 for lipid-rich or phenol containing tissues (Skubatz and Bendich, 1990).

Several isolation methods for organellar DNA from plants using differential centrifugation technique were tested (Triboush et al., 1998; Scotti et al., 2001; Virupakshi and Naik, 2007; Hu et al.,

TABLE 1. LIST OF PRIMERS USED FOR THE AMPLIFICATION OF SPECIFIC GENES FROM MITOCHONDRIAL, NUCLEAR AND CHLOROPLAST GENOMES

\begin{tabular}{llcc}
\hline Organelle & Target region (gene) & Primer sequence & Amplicon size (bp) \\
\hline Mitochondrion & coxIII & F: 5'-CCGTAGGAGGTGTGATGT-3' & 680 \\
& & R: 5'-CTCCCCACCAATAGATAGAG-3' \\
Nucleus & Actin & F: 5'-GAGAGAGCGTGCTACTCATC-3' & 230 \\
& & R: 5'-CGGAAGTGCTTCTGAGATCC-3' & 590 \\
Chloroplast & trnL (UAA) & F: 5'-CGAAATCGGTAGACGCTACG-3' & \\
& intron & R: 5'-GGGGATAGAGGGACTTGAAC-3' & \\
\hline
\end{tabular}


2012). The method by Virupakshi and Naik (2007), with modifications (Method I), was the simplest and easiest. This method employs low speed centrifugation that removed cell wall fragments, starch grains, nuclei and intact plastids followed by a higher centrifugation speed which sedimented the intact mitochondria. In addition, elimination of nuclear DNA contamination was achieved by DNase treatment with a standard phenol/ chloroform step to purify the mtDNA. Generally, mitochondria are enriched through differential centrifugation, followed by removal of nuclear DNA adhering to the external side of the organelle by using DNase treatment. This differential centrifugation technique using oil palm young leaf tissue provided adequately good quality $\mathrm{mtDNA}$ for restriction enzyme analysis (data not shown). MtDNA yield from young leaf tissue was 25-50 $\mu \mathrm{g}$ $\mathrm{g}^{-1}$ of tissue. A similar approach was reported by $\mathrm{Hu}$ et al. (2012) and Klein et al. (1998) whereby tender green leaf tissues were used for mtDNA isolation. Approximately 2-10 $\mu \mathrm{g} \mathrm{g}^{-1}$ tissue of mtDNA from rapeseed leaves and 10-50 $\mu \mathrm{g} \mathrm{g}^{-1}$ tissue of mtDNA from Arabidopsis leaves were isolated, respectively. Although this method was technically less laborious compared to the other two, it was not suitable for oil palm green leaf tissues as the quality of the isolated mtDNA was not up to par.

This led to the testing of density gradient centrifugation-based approaches using either sucrose (Method II) or Percoll (Method III). Despite their tediousness, these approaches were proven to efficiently isolate mitochondria from other plants (Hausmann et al., 2003). Sucrose, which is more cost effective and most commonly used for density centrifugation was utilised in Method II (Hanson et al., 1986). Purification of mitochondria and mtDNA was achieved using discontinuous sucrose gradient centrifugation and $\mathrm{CsCl}$ density gradient respectively. Isolation of organelles using discontinuous sucrose gradient showed that the upper 1.2/1.6 M interphase band tends to be more contaminated with thylakoid membranes, indicated as a predominantly dark green band (Figure 1). The light green band between the $1.6 \mathrm{M}$ and $2 \mathrm{M}$ range contained most of the mitochondria but could be contaminated by some thylakoid membranes. The sucrose gradient, however, may not be suitable as a separation media for plants with high starch content, which would result in poor phase separation of the mitochondria (Hrubec et al., 1985). Hence, sucrose gradient centrifugation was deemed not appropriate for mitochondria isolation from oil palm leaves since this approach could not separate the thylakoid membranes from mitochondria efficiently.

With this in mind, a better separation media was tested and this was incorporated in the third isolation procedure. Percoll has been used in mitochondria purification from green and non-green tissues via continuous or discontinuous Percoll gradients (Eubel et al., 2007). The usage of Percoll allowed the separation of mitochondria and thylakoid membranes from green tissues (Lang and Burger, 2007; Mühlenhoff, 2010), and reduced chlorophyll contamination by $88.5 \%$ (Jackson et al., 1979). Mitochondria isolated from soyabean leaves purified on a discontinuous Percoll gradient contained only $4 \%$ chlorophyll contamination (Hrubec et al., 1985). In addition, studies on intracellular protein transport between mitochondria and chloroplast in spinach leaves and proteome studies in tobacco and Arabidopsis leaves were also conducted using discontinuous Percoll gradients (Glaser et al., 1995; Michalecka et al., 2004; Chen et al., 2010).

After testing several methods including one that uses a continuous Percoll gradient (Keech et al., 2005), we found that the most suitable method to isolate mitochondria from oil palm green leaves is one that incorporates a discontinuous Percoll step gradient. Percoll step gradients are often used to aid the focusing of mitochondria fractions to an interface between Percoll concentrations (Eubel et al., 2007). This method, comprising four basic steps, was modified from Binder and Grohmann (1995), Binder (1995) and Mourad (1998). Firstly, mitochondria were separated from cellular debris, plastids and nuclei by differential centrifugation, followed by DNase treatment. The effectiveness of the DNase treatment requires penetration of the DNase enzyme into non-intact contaminated plastids and nuclear debris. Sufficient mitochondrial integrity is also important to prevent the enzyme from entering the organelles.

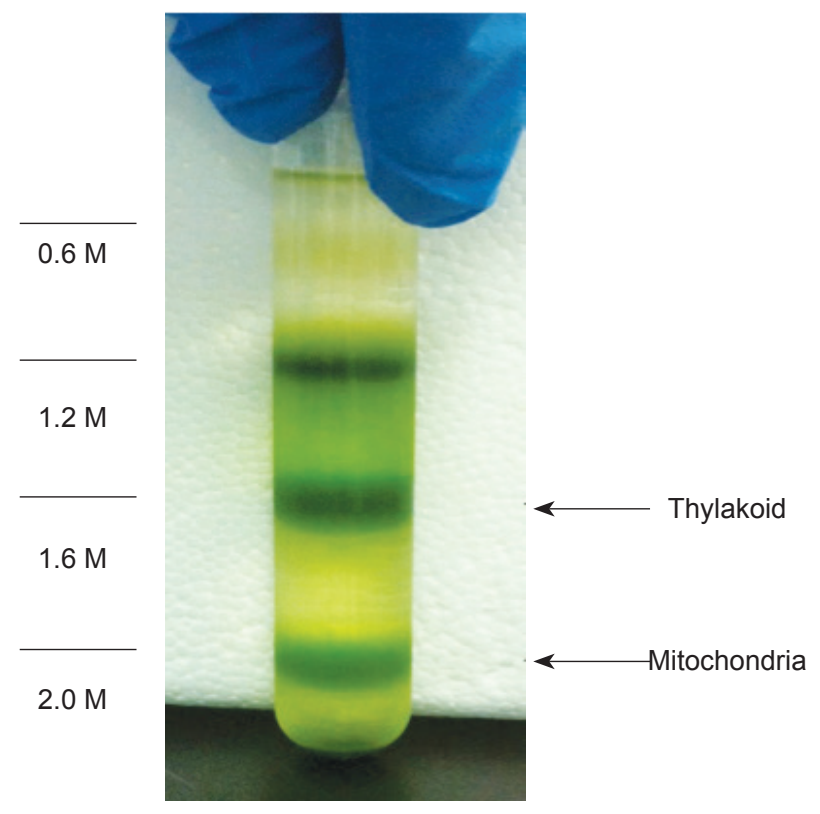

Figure 1. Purification of plant mitochondria by discontinuous sucrose gradient centrifugation (Method II). Distribution of different fractions and the relative position of oil palm mitochondria are shown. Sucrose step gradients $(0.6$ to $2.0 \mathrm{M})$ are indicated on the left. 
Disruption or homogenisation of the crude lysate before layering onto the three Percoll gradient layers is also crucial. This step eventually results in the focusing of a yellowish mitochondrial band between the $28 \%$ and $45 \%$ gradient. No interphase would be observed if the sample was not properly disrupted or excessive disruption had taken place during homogenisation (data not shown). The greenish band observed between the $14 \%$ and $28 \%$ interface corresponded to the thylakoid membrane layer (Figure 2). Finally, mtDNA was further

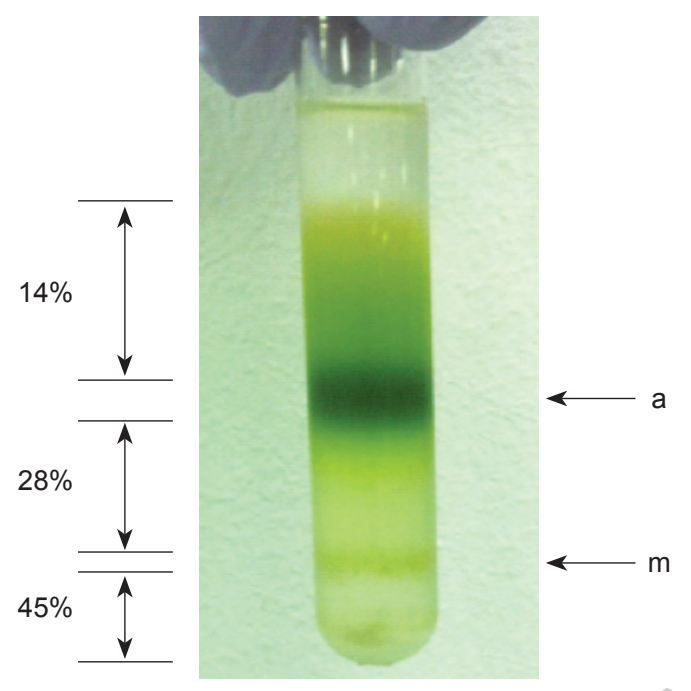

Figure 2. Purification of plant mitochondria by Percoll gradient centrifugation. Position of the three-step Percoll gradient, 45\%, 28\% and $14 \%$ Percoll solution, are shown on the left. Plastids (a) are concentrated at the 14\%-28\% interphase and mitochondria $(\mathrm{m})$ at the $28 \%-45 \%$ interphase. purified on $\mathrm{CsCl}$ density gradients. A single band was observed on agarose gel for mtDNA isolated using sucrose and Percoll gradients. The advantages and disadvantages of each isolation method are summarised in Table 2.

\section{Method III Provided Good Quality mtDNA with Minimal Chloroplast DNA Contamination}

UV absorbance and Qubit fluorometer analysis was used to determine the purity and concentration of the mtDNA (Table 3). The ideal $\mathrm{A}_{260} / \mathrm{A}_{280}$ and $\mathrm{A}_{260} / \mathrm{A}_{230}$ ratios are considered to be within 1.81.9 and 2.0-2.2, respectively (Sambrook et al., 1989). According to the $A_{260} / A_{280}$ values obtained, Methods II and III provided higher mtDNA purity, indicating low protein contamination. MtDNA isolated using Method I also contained RNA (Figure 3a).

All extraction methods provided mtDNA with $\mathrm{A}_{260} / \mathrm{A}_{230}$ ranging from $0.56 \pm 0.28$ to $1.35 \pm 0.08$. However, mtDNA isolated using Method III showed the highest value while Method I produced mtDNA with the lowest purity, suggesting contamination by polysaccharides, salts or organic solvents (Table 3). These contaminants may inhibit downstream applications (Healey et al., 2014). Therefore, Method I did not consistently provide good quality mtDNA, and could not be digested with restriction enzymes as well (data not shown). Impurities in DNA can lead to inaccurate measurement of DNA concentrations particularly through absorbance measurement. Therefore, Qubit fluorescence measurement indicated that mtDNA

TABLE 2. COMPARISON OF MIDNA EXTRACTION METHODS FOR OIL PALM LEAF TISSUES

\begin{tabular}{|c|c|c|c|}
\hline \multirow{2}{*}{\multicolumn{2}{|c|}{$\begin{array}{l}\text { Comparison } \\
\text { features }\end{array}$}} & \multicolumn{2}{|l|}{ Methods } \\
\hline & & II & III \\
\hline \multirow{3}{*}{$\begin{array}{l}\text { Isolation and } \\
\text { purification of } \\
\text { mitochondrial } \\
\text { deoxyribonucleic } \\
\text { acid (mtDNA) }\end{array}$} & $\begin{array}{l}\text { MtDNA was extracted using high } \\
\text { ionic alkaline buffer } \\
\text { Purification of mtDNA using }\end{array}$ & $\begin{array}{l}\text { Discontinuous sucrose } \\
\text { gradient was used to isolate } \\
\text { mitochondria from other cell } \\
\text { components }\end{array}$ & $\begin{array}{l}\text { Discontinuous Percoll step } \\
\text { gradient was used to isolate } \\
\text { mitochondria from other cell } \\
\text { components }\end{array}$ \\
\hline & $\begin{array}{l}\text { chloroform-isoamyl alcohol } \\
\text { extraction }\end{array}$ & $\begin{array}{l}\text { Require careful dilution of } \\
\text { mitochondrial fraction in } \\
\text { isosmotic conditions }\end{array}$ & $\begin{array}{l}\text { Allow rapid separation under } \\
\text { isosmotic and low viscosity } \\
\text { conditions }\end{array}$ \\
\hline & & $\begin{array}{l}\text { Cesium chloride }(\mathrm{CsCl}) \text { gradient } \\
\text { required for further purification } \\
\text { from impurities }\end{array}$ & $\begin{array}{l}\mathrm{CsCl} \text { gradient required for further } \\
\text { purification }\end{array}$ \\
\hline Protocol time & Two days & Seven days & Seven days \\
\hline Simplicity of procedure & Less laborious & Tedious & Tedious \\
\hline Cost & Low & Low & Medium \\
\hline \multirow[t]{2}{*}{ Others } & - & $\begin{array}{l}\text { Effective separation of bacteria } \\
\text { from mitochondria }\end{array}$ & $\begin{array}{l}\text { Effective separation of } \\
\text { mitochondria from thylakoid } \\
\text { membrane }\end{array}$ \\
\hline & & $\begin{array}{l}\text { Inadequate separation for plants } \\
\text { with high starch content }\end{array}$ & \\
\hline
\end{tabular}


yield using Method III was the highest though absorbance readings indicated otherwise (Table 3 ).

The integrity of mtDNA and preliminary validation of mtDNA purity was analysed using gel electrophoresis and restriction enzyme digestion respectively. The restriction digest patterns of purified mtDNA can be validated by comparing with that of total plant DNA (Klein et al., 1998). MtDNA isolated using Methods I and III was intact and several well-defined bands were obtained after EcoRV digestion (Figures $3 a$ and 3c). Well-separated bands with a total size of more than $100 \mathrm{kbp}$ can be obtained when restriction analysis was performed on most organellar DNA (Lang and Burger, 2007). On the other hand, mtDNA isolated with Method II was slightly degraded and its restriction digest profiles also produced a background smear, suggesting partial mtDNA degradation and nuclear DNA contamination (Figure 3b). The total cellular DNA positive control showed an intact band and produced a continuous smear when digested with EcoRV (Figure 3d).

Further evaluation of mtDNA purity was conducted using PCR. Total cellular DNA was used as a positive control as it contains nuclear, chloroplast and mtDNA (Lutz et al., 2011). The chloroplast specific universal primers for the $\operatorname{trn} \mathrm{L}$ (UAA) intron evaluated cpDNA extract from oil palm leaves (Ho et al., 2015). PCR amplification for the cytochrome c oxidase subunit III (coxIII) of mtDNA, actin from nuclear DNA and chloroplast non-coding $\operatorname{trn} \mathrm{L}$ (UAA) gene from the isolated mtDNA was successful (Figure 4). The coxIII PCR product was amplified from mtDNA isolated with all extraction methods, verifying that mtDNA was successfully isolated (Figure 4a). Low amounts of chloroplast co-sedimenting with mitochondria will hinder the purification of mtDNA from green tissues (Hrubec et al., 1985; Klein et al., 1998; Møller and Rasmusson, 2015). Some cpDNA was detected in the isolated mtDNA from all methods (Figure $4 b$ ). However, intensity of the PCR product for the chloroplast trnL (UAA) from mtDNA of Method III was fainter comparatively, suggesting a lower cpDNA contamination. MtDNA from Methods I and III did not generate the actin PCR product, demonstrating that the mtDNA was free from nuclear DNA contamination. However, mtDNA of Method II may contain nuclear DNA contamination, as shown by the amplified actin PCR product (Figure 4).

TABLE 3. QUALITY AND YIELD OF mIDNA EXTRACTED USING THE THREE METHODS

\begin{tabular}{lccc}
\hline Parameters & \multicolumn{3}{c}{ Methods } \\
\cline { 2 - 4 } & I & II & III \\
\hline $\mathrm{A}_{260} / \mathrm{A}_{280}$ ratio & $2.04 \pm 0.04$ & $1.87 \pm 0.17$ & $1.82 \pm 0.08$ \\
$\mathrm{~A}_{260} / \mathrm{A}_{230}$ ratio & $0.56 \pm 0.28$ & $1.09 \pm 0.16$ & $1.35 \pm 0.08$ \\
$\begin{array}{c}\text { Yield }(\mu \mathrm{g} \text { mtDNA/g } \\
\text { tissue) - Qubit }\end{array}$ & $2.03 \pm 0.43$ & $5.23 \pm 0.57$ & $6.30 \pm 0.51$ \\
\hline
\end{tabular}

Note: Data is presented as mean $\pm S D$ of three biological replicates.

The three-step discontinuous Percoll gradient used in Method III reproducibly provided the best quality mtDNA from oil palm green leaves, whereby the quality was verified through successful restriction enzyme digestion. Our results strongly demonstrated that this method yielded mtDNA with the least plastid DNA contamination while providing good yields and purity. This enriched
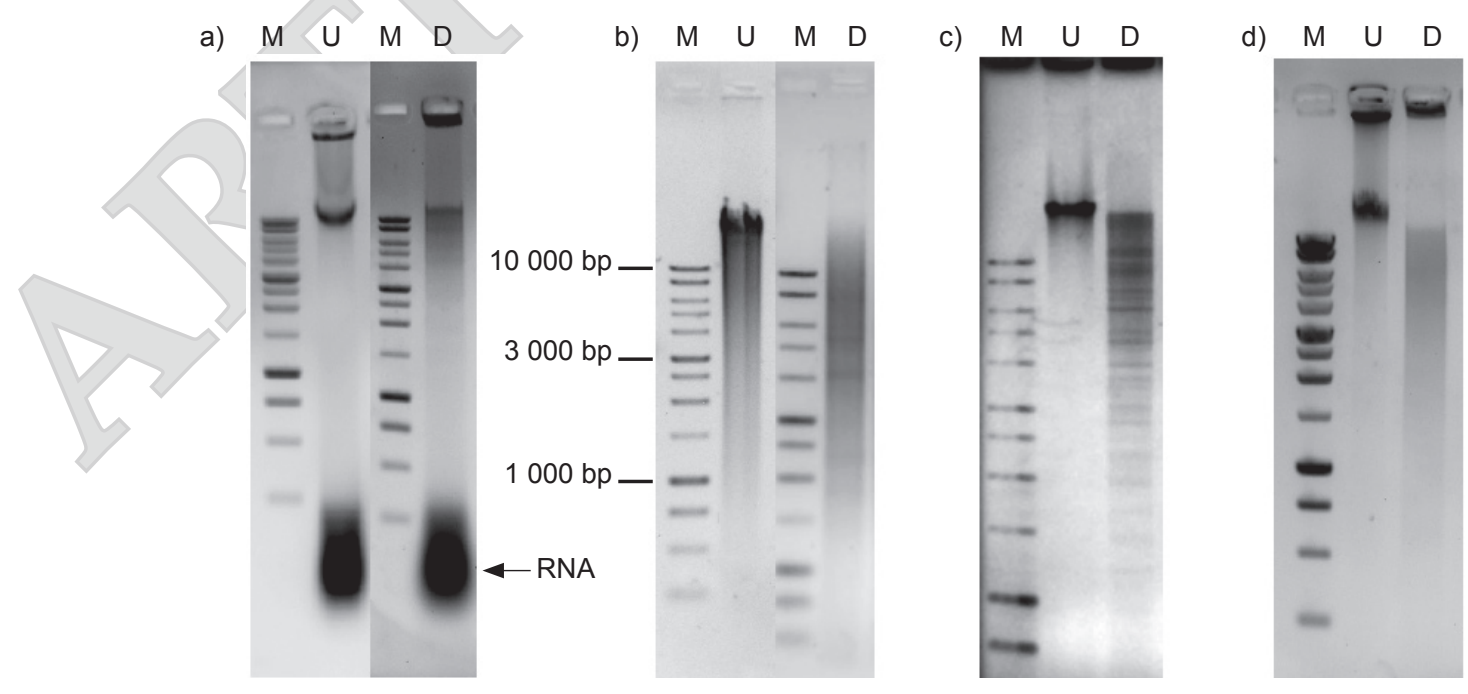

Figure 3. Evaluation of leaf mitochondrial deoxyribonucleic acid (mtDNA) isolated using all three methods via gel electrophoresis and restriction digestion analysis. MtDNA isolated using (a) Method I, (b) Method II, (c) Method III, and (d) with total cellular DNA of oil palm as positive control. Lanes U: $1 \mu \mathrm{g}$ of mtDNA, D: $1 \mu \mathrm{g}$ mtDNA digested with EcoRV, M: $1 \mathrm{~kb}$ DNA ladder (promega). 


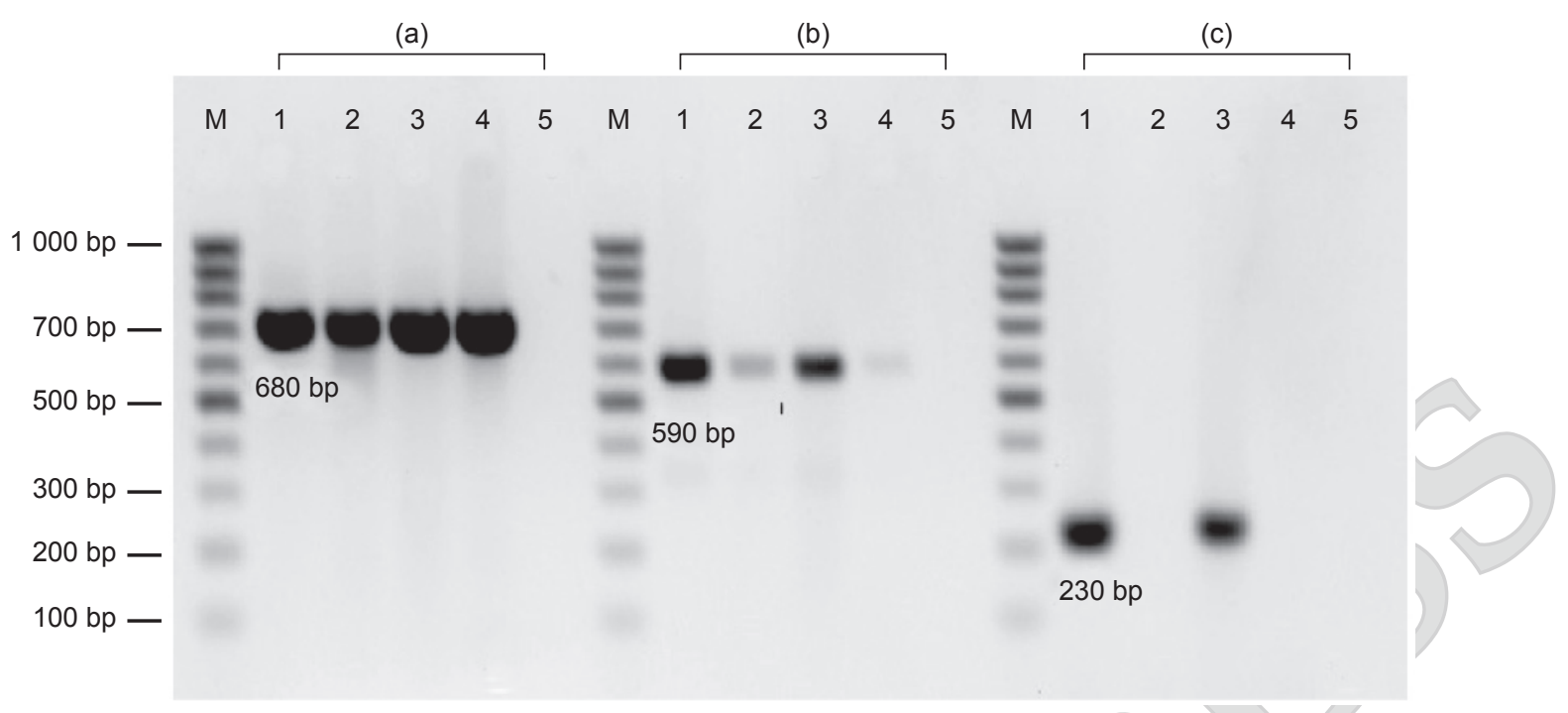

Figure 4. The polymerase chain reaction (PCR) amplification of mitochondrial deoxyribonucleic acid (mtDNA) isolated using the three methods. (a) coxIII product amplified from $m t D N A$; (b) trn L product amplified from chloroplast DNA (cpDNA); (c) actin product amplified from nuclear DNA. DNA templates used in PCR for Lane 1: positive control of total cellular DNA of oil palm ( $\mathrm{g} D N A), 2: m t D N A$ from Method I, 3: mtDNA from Method II, 4: mtDNA from Method III, 5: no template negative control, M: 100 bp ladder (promega).

mtDNA can be used to generate mitochondrial genome information for further studies on nuclearmitochondrial genetic interactions.

\section{ACKNOWLEDGEMENT}

The authors would like to thank the DirectorGeneral of MPOB for permission to publish this article. Our deepest appreciation goes to Azizah Mokri and Shamshulbahri Abd Manap of the Breeding and Tissue Culture Unit, MPOB, Mohd Mustakim Mohamad of MPOB Bagan Datuk, Perak and Rahimah Abdul Rahman of Genomics Unit, MPOB for their invaluable technical support and advice throughout this study. This study was funded by MPOB.

\section{REFERENCES}

Binder, S (1995). Mitochondrial nucleic acid purification and analysis. Plant Gene Transfer and Expression Protocols (Jones, H ed.). Humana Press, New Jersey. p. 383-390.

Binder, S and Grohmann, L (1995). Isolation of Mitochondria. Plant Gene Transfer and Expression Protocols (Jones, H ed.). Humana Press, New Jersey. p. 377-382.

Chen, R H; Liu, W; Zhang, G S and Ye, J X (2010). Mitochondrial proteomic analysis of cytoplasmic male sterility line and its maintainer in wheat (Triticum aestivum L.). Agric. Sci. China, 9: 771-782. DOI: 10.1016/S1671-2927(09)60154-1.
Day, D A; Neuburger, M and Douce, R (1985). Biochemical characterization of chlorophyll-free mitochondria from pea leaves. Funct. Plant Biol. DOI: $10.1071 /$ pp9850219.

Day, J (1997). Isolation of nuclear, chloroplast and mitochondrial DNA from plants. Biochem. Educ., 25: 41-43. DOI: 10.1016/S0307-4412(96)00144-6.

Douce, R; Moore, A L and Neuburger, M (1977). Isolation and oxidative properties of intact mitochondria isolated from spinach leaves. Plant Physiol., 60: 625-628. DOI: 10.1104/pp.60.4.625.

Doyle, J J and Doyle, J L (1990). Isolation of plant DNA from fresh tissue. Focus, 12: 13-15.

Duminil, J M; Pemonge, H and Petit, R J (2002). A set of 35 consensus primer pairs amplifying genes and introns of plant mitochondrial DNA. Mol. Ecol. Notes, 2: 428-430. DOI: 10.1046/j.1471-8278.

Eubel, H; Heazlewood, J L and Millar, A H (2007). Isolation and subfractionation of plant mitochondria for proteomic analysis. Methods Mol. Biol., 355: 49-62. DOI: 10.1385/1-59745-227-0:49.

Glaser, E; Knorpp, C; Hugosson, $\mathrm{M}$ and von Stedingk, E (1995). Macromolecular movement into mitochondria. Methods Cell Biol. (Galbraith, D W; Bourque, D P and Bohnert, H J eds.). Academic Press Inc., California. p. 269-281.

Hanson, M R; Boeshore, M L; McClean, P E; O'Connell, M A and Nivison, H T (1986). The isolation of mitochondria and mitochondrial 
DNA. Methods in Enzymology (Weissbach, A and Weissbach, H eds.). Academic Press, New York. p. 437-453.

Hausmann, N; Werhahn, W; Huchzermeyer, B; Braun, H P and Papenbrock, J (2003). How to document the purity of mitochondria prepared from green tissue of pea, tobacco and Arabidopsis thaliana. Phyt-Ann. Rei. Bot., 43: 215-229.

Healey, A; Furtado, A; Cooper, T and Henry, R J (2014). Protocol: A simple method for extracting next-generation sequencing quality genomic DNA from recalcitrant plant species. Plant Methods, 10: 21. DOI: $10.1186 / 1746-4811-10-21$.

Ho, C M; Ooi, L C L; Tan, S G; Ho, C L and Singh, R (2015). A chloroplast DNA (cpDNA) extraction protocol for diversity analysis of oil palm (Elaeis spp.). J. Oil Palm Res. Vol. 27: 306-314.

Hrubec, T C; Robinson, J M and Donaldson, R P (1985). Isolation of mitochondria from soybean leaves on discontinuous percoll gradients. Plant Physiol., 77: 1010-1012. DOI: 10.1104/pp.77.4.1010.

$\mathrm{Hu}, \mathrm{Z}$; Zhan, G; Wang, H and Hua, W (2012). A simple method for isolating chloroplast DNA and mitochondria DNA from the same rapeseed green leaf tissue. J. Integr. Agric., 11: 1212-1215. DOI: 10.1016/S2095-3119(12)60117-8.

Jackson, C; Dench, J E; Hall, D O and Moore, A L (1979). Separation of mitochondria from contaminating subcellular structures utilizing silica sol gradient centrifugation. Plant Physiol., 64: 150153. DOI: $10.1104 /$ pp.64.1.150.

Keech, O; Dizengremel, $\mathrm{P}$ and Gardeström, P (2005). Preparation of leaf mitochondria from Arabidopsis thaliana. Physiol. Plant., 124: 403-409. DOI: 10.1111/j.1399-3054.2005.00521.x.

Klein, M; Hiesel, R; Andre, C and Brennicke, A (1998). Purification of mitochondrial DNA from green tissues of Arabidopsis. Arabidopsis Protocols (Martinez-Zapater, J M and Salinas, J eds.). Humana Press, New Jersey. p. 79-84.

Lang, B F and Burger, G (2007). Purification of mitochondrial and plastid DNA. Nat. Protoc., 2: 652660. DOI: 10.1038 / nprot.2007.58.

Lutz, K A; Wang, W; Zdepski, A and Michael, T P (2011). Isolation and analysis of high quality nuclear DNA with reduced organellar DNA for plant genome sequencing and resequencing. BMC Biotechnol., 11: 54. DOI: 10.1186/1472-6750-1154.
Mackenzie, S A (1994). Isolation of plant mitochondria and mitochondrial nucleic acids. Plant Mol. Biol. Man., (Gelvin, S B and Schilperoort, R A eds.). Springer, Dordrecht. p. 203-214.

Michalecka, A M; Agius, S C; Møller, I M and Rasmusson, A G (2004). Identification of a mitochondrial external NADPH dehydrogenase by overexpression in transgenic Nicotiana sylvestris. Plant J., 37: 415-425. DOI: 10.1046/j.1365313X.2003.01970.x.

Moore, A L; Fricaud, A C; Walters, A J and Whitehouse, D G (1993). Isolation and purification of functionally intact mitochondria from plant cells. Methods Mol. Biol., 19: 133-139. DOI: 10.1385/089603-236-1:133.

Møller, I M and Rasmusson, A G (2015). Isolation of mitochondria. Plant Physiology and Development, Sixth edition. Companion Website (Taiz, L; Zeiger, E; Møller, I M and Murphy, Aeds.). Sinauer Associates, USA. http://6e.plantphys.net/topic12.01.html, accessed on 16 November 2017.

Mourad, G S (1998). Chloroplast DNA isolation. Methods in Molecular Biology (Martinez-Zapater, J M and Salinas, J eds.). Humana Press, Madrid. p. 7177 .

Mühlenhoff, U (2010). Mitochondria: Methods for preparation. Encycl. Life Sci.: 1-11. DOI: 10.1002/9780470015902.a0002601.pub2.

Neuburger, M; Journet, E P; Bligny, R; Carde, J P and Douce, R (1982). Purification of plant mitochondria by isopycnic centrifugation in density gradients of Percoll. Arch. Biochem. Biophys., 217: 312-323. DOI: 10.1016/0003-9861(82)90507-0.

Rahman, A S and Huber, D J (1996). Isolation and physiological properties of intact mitochondria from bell pepper (Capsicum annum) fruit. J. Plant Physiol., 149: 677-682. DOI: 10.1016/S0176-1617(96)80091-5.

Sambrook, J; Fritsch, E F and Maniatis, T (1989). Molecular Cloning: A Laboratory Manual. Second edition. Vol. 1, 2 and 3. Cold Spring Harbour, New York.

Scotti, N; Cardi, T and Marechaldrouard, L (2001). Mitochondrial DNA and RNA isolation from small amounts of potato tissue. Plant Mol. Biol. Report., 19: 67. DOI: 10.1007 / BF02824080.

Skubatz, H and Bendich, A J (1990). Isolation of mitochondria and mtDNA. Plant Molecular Biology Manual (Gelvin, S; Schilperoort, R and Verma, D eds.). Springer Netherlands, Dordrecht. p. 1-7. 
Sweetlove, L J; Taylor, N L and Leaver, C J (2007). Isolation of intact, functional mitochondria from the model plant Arabidopsis thaliana. Methods Mol. Biol., 372: 125-136. DOI: 10.1007/978-1-59745-365-3_9.

Taberlet, P; Gielly, L; Pautou, G and Bouvet, J (1991). Universal primers for amplification of three non-coding regions of chloroplast DNA. Plant Mol. Biol., 17: 1105-1109. DOI: 10.1007/ Bf00037152.
Triboush, S O; Danilenko, N G and Davydenko, O G (1998). A method for isolation of chloroplast DNA and mitochondrial DNA from sunflower. Plant Mol. Biol. Report., 16: 183. DOI: 10.1023/ A:1007487806583.

Virupakshi, S and Naik, G R (2007). Purification of DNA from chloroplast and mitochondria of sugarcane. Curr. Sci., 92: 1613-1619. 